\title{
Hematologic and Biosynthetic Studies in Homozygous Hemoglobin Constant Spring
}

\author{
S. Derry, W. G. Wood, M. Pippard, J. B. Clegg, \\ D. J. Weatherall \\ Medical Research Council Molecular Haematology Unit, Nuffield \\ Department of Clinical Medicine, University of Oxford, \\ John Radcliffe Hospital, Oxford, OX3 9DU, England \\ S. N. Wickramasinghe, J. Darley, S. Fucharoen, \\ and $P$. Wasi \\ Department of Haematology, St. Mary's Hospital Medical \\ School, London; Department of Haematology, John Radcliffe \\ Hospital, Oxford; Thalassemia Centre, Mahidol University, \\ Bangkok; and Division of Haematology, Department of Medicine, \\ Siriraj Hospital, Bangkok
}

A moglobin Constant Spring ( $\alpha^{\mathrm{CS}}$ chain of $\mathrm{HbCS}$ ) are produced in low amounts such that the $\alpha^{\mathrm{CS}}$-gene acts as a form of $\alpha$-thalassemia; yet in the homozygous state the pathophysiological effects of this mutant are more severe than in the corresponding conditions that result from $\alpha$ globin gene deletions. In studies designed to examine this discrepancy, we have demonstrated that a significant proportion of red cells produced in an HbCS homozygote has a much reduced red cell life span. Contrary to previous reports, we have been able to demonstrate the expected deficit in $\alpha$-chain production in this condition and have shown that both the cessation of globin chain synthesis in vitro and the destruction of the excess $\beta$-chains occur unusually rapidly. Comparison with various deletion forms of $\alpha$-thalassemia suggests that, in terms of intracellular globin chain precipitates and free $\beta$-chain pool, homozygous $\mathrm{HbCS}$ red cells more closely resemble those of $\mathrm{HbH}$ disease, with three of the four $\alpha$-genes inactivated, than they do the more comparable $\alpha$-thalassemia carriers with only two genes deleted.

Please address all correspondence to Dr. W. G. Wood, MRC Molecular Haematology Unit, John Radcliffe Hospital, Oxford.

Received for publication 27 November 1983 and in revised form 6 February 1984.

J. Clin. Invest.

(c) The American Society for Clinical Investigation, Inc.

$0021-9738 / 84 / 06 / 1673 / 10 \quad \$ 1.00$

Volume 73, June 1984, 1673-1682

\section{Introduction}

Hemoglobin Constant Spring (HbCS), ${ }^{1}$ an abnormal hemoglobin with a frequency of up to $5 \%$ of some populations in Southeast Asia, has $\alpha$-chains that are 172 amino acids long, instead of the normal $141(1,2)$. The elongated $\alpha$-chain is thought to result from a single base substitution in the chain termination codon of the $\alpha 2$-gene, which results in its translation as an amino acid and allows read-through of the normally untranslated $3^{\prime}$ flanking region of the $\alpha$-globin messenger RNA (mRNA) until the next in-phase termination codon is reached. Heterozygotes for $\mathrm{HbCS}$ have $\sim 1 \%$ of the variant in their red cells, instead of the 20 $25 \%$ usually found in heterozygotes for $\alpha$-chain hemoglobin variants. This has been shown to be due to instability of the $\alpha^{\mathrm{CS}}$-mRNA, presumably because of its unusual pattern of translation, rather than to instability of the protein (3). The net effect of the reduced synthesis of $\alpha^{\mathrm{CS}}$-chains is that the $\alpha^{\mathrm{CS}}$-gene acts as a form of $\alpha$-thalassemia, and when it is inherited together with $\alpha^{\circ}$-thalassemia $\left(--/ \alpha^{\mathrm{Cs}} \alpha\right)$ it produces the clinical phenotype of $\mathrm{HbH}$ disease (4).

When compared with other common forms of $\alpha$-thalassemia in Southeast Asia, most of which are due to gene deletions, the $\mathrm{HbCS}$ forms show several unexplained differences. Both heterozygotes $\left(\alpha \alpha / \alpha^{\mathrm{CS}} \alpha\right)$ and homozygotes $\left(\alpha^{\mathrm{CS}} \alpha / \alpha^{\mathrm{CS}} \alpha\right)$ have been reported to show $\alpha / \beta$ globin chain synthesis ratios $>1$, rather than the expected deficit of $\alpha$-chain production $(5,6)$. Furthermore, since the $\alpha^{\mathrm{CS}}$-gene is associated with a very low output of $\alpha$-globin chains, homozygotes should have the same clinical

1. Abbreviations used in this paper: $\mathrm{Hb}$, hemoglobin; $\mathrm{HbA}$ and $\mathrm{HbA}_{2}$, normal adult hemoglobins; $\mathrm{HbF}$, fetal hemoglobin; HbCS, hemoglobin Constant Spring; MCH, mean corpuscular hemoglobin; MCV, mean corpuscular volume; PMSF, phenylmethyl sulfonylfluoride. 
phenotype as individuals homozygous for the deletion form of $\alpha^{+}$-thalassemia $(-\alpha /-\alpha)$ or heterozygous for $\alpha^{\circ}$-thalassemia $(\alpha \alpha /$ $--)$. These individuals are mildly anemic, with microcytic, hypochromic red cells, but show no other clinical abnormalities or changes in their Hb pattern (7). HbCS homozygotes, in contrast, have a moderate hemolytic anemia with splenomegaly, relatively normal red cell indices, and elevated levels of $\mathrm{Hb}$ Barts $\left(\gamma_{4}\right)(6,8,9)$. Furthermore, patients with $\mathrm{HbH}$ disease with only one $\alpha$-gene $(-\alpha /--)$ are less anemic and have less $\mathrm{HbH}$ than those who are heterozygous for both $\alpha^{\circ}$-thalassemia and the HbCS mutation $\left(\alpha^{\mathrm{Cs}} \alpha /--\right)(10,11)$.

In an attempt to clarify some of the unexplained phenotypic differences between HbCS and the deletion forms of $\alpha$-thalassemia, we have carried out extensive clinical, hematological, and biochemical studies on a patient homozygous for HbCS.

\section{Methods}

Patients. P.P., a 32-yr-old Thai male, homozygous for HbCS, gave informed consent for these studies, which were carried out over a 2-wk period in Oxford. Apart from recurrent jaundice as a child, he has had no symptoms. Mild icterus and hepatosplenomegaly $(4$ and $3 \mathrm{~cm}$, respectively) were the only abnormal physical findings; bone $x$-rays of chest and skull were normal.

For comparison, studies were also carried out on several patients with various forms of $\alpha$-thalassemia that were shown by restriction enzyme mapping to be due to gene deletions. The two patients with $\mathrm{HbH}$ disease were of Filipino and Chinese origin; they had the typical features of this condition, with $\mathrm{HbH}$ levels of 11 and $8 \%$, respectively, and reticulocyte counts of 7 and 5\%. Two patients of Sudanese and Nigerian origins, homozygous for $\alpha^{+}$-thalassemia $(\alpha-/ \alpha-)$, also had typical hematological findings but were clinically unaffected, as was the $\alpha^{\circ}$ thalassemia heterozygote $(\alpha \alpha /--)$ (previously reported as II1 in family $\mathrm{L}$ of reference 12 ).

Hematologic studies and hemoglobin analysis. Hematologic studies on blood and bone marrow were performed by standard procedures. Methods for hemoglobin analysis by starch gel electrophoresis, quantitative analysis on cellulose acetate, and measurement of fetal $\mathrm{Hb}(\mathrm{HbF})$ by alkaline denaturation have been described previously (13).

For electron microscopy, aspirated bone marrow was taken into heparinized Hanks' solution, fixed in glutaraldehyde $(2.5 \%$ in $0.1 \mathrm{M}$ phosphate buffer, $\mathrm{pH}$ 7.3), and processed for transmission electron microscopy (14). At least 600 consecutive erythroid cell profiles were assessed for the presence of precipitated globin chains.

Red cell fractionation. Age stratification of red cells was achieved by centrifugation of a column of $14 \mathrm{ml}$ packed red cells at $200,000 \mathrm{~g}$ for $60 \mathrm{~min}$ at $4^{\circ} \mathrm{C}$.

Bone marrow erythroid cells were fractionated according to their degree of maturity on bovine serum albumin gradients (15).

Ferrokinetic studies. Ferrokinetic studies were carried out after intravenous injection of $9 \mathrm{ml}$ of the patient's plasma that had been labeled with $6 \mu \mathrm{Ci}{ }^{59} \mathrm{Fe}$ ferric citrate (specific activity $10 \mu \mathrm{Ci} / \mu \mathrm{g}$ iron; Radiochemical Centre, Amersham Corp., Amersham, England). Subsequent determination of plasma and erythroid iron turnover was as described (16). Plasma iron and total iron binding capacity were determined by standard methods $(17,18)$.

Red cell survival studies were carried out using the patient's cells labeled with ${ }^{51} \mathrm{Cr}$ by the sodium chromate/acid-citrate-dextrose method. Subsequent peripheral red cell ${ }^{51} \mathrm{Cr}$ counts were corrected for elution (19).

Surface ${ }^{59} \mathrm{Fe}$ and ${ }^{51} \mathrm{Cr}$ counts over heart, sacrum, liver, and spleen were measured with a collimated sodium iodide scintillation probe. The injection of ${ }^{51} \mathrm{Cr}$-labeled red cells was delayed until $30 \mathrm{~min}$ after that of ${ }^{59} \mathrm{Fe}$-labeled plasma to allow determination at each site of the proportion of ${ }^{59} \mathrm{Fe}$ which would cross-count with ${ }^{51} \mathrm{Cr}$. All later ${ }^{51} \mathrm{Cr}$ counts were then corrected for ${ }^{59} \mathrm{Fe}$ cross-counts and analyzed for any excess accumulation of ${ }^{51} \mathrm{Cr}$ in liver and spleen (20).

Globin chain synthesis studies. Peripheral blood and bone marrow samples were incubated with $\left[{ }^{3} \mathrm{H}\right]$ leucine for increasing periods of time (21). For peripheral blood incubations, reticulocyte enrichment was unnecessary in the $\mathrm{HbCS}$ homozygote and the patients with $\mathrm{HbH}$ disease but was carried out in the other $\alpha$-thalassemia cases. White cells were removed by cellulose columns (22) in all cases. For determination of the total globin chain synthesis pattern, aliquots were removed from the incubation mixture at various times and added directly to $2 \% \mathrm{HCl}$ in acetone at $-20^{\circ} \mathrm{C}$, without prior washing.

In pulse-chase experiments, incubated samples were washed three times in reticulocyte saline $\left(\mathrm{NaCl}, 0.13 \mathrm{M} ; \mathrm{KCl}, 0.005 \mathrm{M} ; \mathrm{MgCl}_{2} \cdot 6 \mathrm{H}_{2} \mathrm{O}\right.$, $0.0024 \mathrm{M}$ ). Fresh incubation medium that contained $10 \mathrm{mM}$ nonradioactive leucine was added to half of the sample and the incubation was continued for $2 \mathrm{~h}$ more, while the other half was immediately converted to globin by acid-acetone precipitation. The reincubated aliquot was similarly converted to globin, without further processing.

For gel filtration, incubated samples were washed, freed of membranes by centrifugation at $100,000 \mathrm{~g} 30 \mathrm{~min}$, and loaded immediately onto Sephadex G-75 columns in 0.05 Tris- $\mathrm{HCl}$, pH 7.4, at $4^{\circ} \mathrm{C}(15)$. After the radioactive profile of the eluate had been obtained, appropriate fractions were pooled, nonradioactive autologous hemolyzate $(50 \mathrm{mg})$ was added as carrier, and globin was precipitated with acid acetone for chain separating.

For Amberlite CG-50 (British Drug Houses Ltd., Poole, England) chromatography, stroma-free samples were dialyzed overnight against three changes of developer 2 (23) and loaded onto the column in the same buffer at $4^{\circ} \mathrm{C}$. When the fast-moving hemoglobins $(\mathrm{HbH}$ and $\mathrm{Hb}$ Barts) had been eluted, the column was equilibrated at $25^{\circ} \mathrm{C}$ for elution of the remaining hemoglobins (normal adult $\mathrm{Hb}\left[\mathrm{HbA}, \mathrm{HbA}_{2}\right]$ ) (24). Pooled fractions were converted to globin for chain separation as described above.

Separation of globin chains from all the above samples was carried out by carboxymethyl-cellulose chromatography $(21,25)$ in $8 \mathrm{M}$ urea2-mercaptoethanol, using a gradient of $0.005-0.033 \mathrm{M} \mathrm{Na}_{2} \mathrm{HPO}_{4}, \mathrm{pH}$ 6.8. Specific activities of the peak tubes were measured after dialysis against $0.5 \%$ formic acid and expressed as counts per minute per milligram, using appropriate extinction coefficients (21).

\section{Results}

\section{Hematologic studies}

At the time of study the hematologic findings in P.P. were as follows: white blood cells, $9.0 \times 10^{9} /$ liter; erythrocytes, 4.38 $\times 10^{12} / \mathrm{liter}$; $\mathrm{Hb}, 11.5 \mathrm{~g} / \mathrm{dl}$; hematocrit, 0.38 ; mean corpuscular volume (MCV), $87.0 \mathrm{fl}$; mean corpuscular $\mathrm{Hb}(\mathrm{MCH}), 26.3 \mathrm{pg}$; mean corpuscular $\mathrm{Hb}$ concentration, $30.2 \mathrm{~g} / \mathrm{dl}$; and reticulocytes, $11.5 \%$. The peripheral blood film showed polychromasia and anisocytosis, with marked basophilic stippling. The serum bil- 
irubin level was raised to $74 \mu \mathrm{mol} / \mathrm{liter}$, but no bilirubin or urobilinogen was detectable in the urine. Other biochemical measurements were normal, as were serum folate and $B_{12}$ levels. Serum haptoglobin was undetectable and serum ferritin was $363 \mu \mathrm{g} / \mathrm{liter}$.

The osmotic fragility curve on fresh blood was within the normal range ( $50 \%$ lysis at $0.435 \% \mathrm{NaCl}$, control $0.45 \%$ ) with no evidence of subpopulations more or less sensitive to lysis. However, after $24 \mathrm{~h}$ of storage the red cells showed a markedly increased resistance ( $50 \%$ lysis at $0.26 \% \mathrm{NaCl}$ vs $0.545 \%$ in the control). Autohemolysis showed 1.40 and $3.35 \%$ lysis after $48 \mathrm{~h}$ with and without glucose, respectively. The whole-blood oxygen dissociation curve was shifted left slightly, with an oxygen pressure at $50 \% \mathrm{Hb}$ saturation of $24.5 \mathrm{mmHg}$ (control 29.0 $\mathrm{mmHg}$ ) and a 2-3-diphosphoglycerate level of $6.55 \mathrm{mmol} / \mathrm{liter}$.

Red cell enzyme measurements showed normal levels of glucose-6-phosphate dehydrogenase, 6-phosphogluconate, adenosine deaminase, glucosephosphate isomerase, phosphofructokinase, lactic acid dehydrogenase, glyceraldehyde phosphate dehydrogenase, and aldolase, with increased levels of pyruvate kinase, hexokinase, glutathione peroxidase, and erythrocyte glutathione reductase, consistent with the high reticulocyte count. Paranitrophenol and pyridine 5'-nucleotide levels were also slightly increased.

A bone marrow aspirate showed hypercellularity that was mainly due to erythroid cells (myeloid/erythroid, 1:3.1) with marked basophilic stippling of the late normoblasts. Macrophage iron was moderately increased and siderotic granules were seen in many of the erythroid precursors. Under the electron microscope, inclusion bodies were observed in the cytoplasm of the erythroblasts (Fig. 1). Approximately $4 \%$ of the cells con- tained branching inclusions similar in appearance to those seen in $\mathrm{HbH}$ disease, while in $0.6 \%$ of the erythroblasts, multiple rounded inclusion bodies, similar in appearance to those found in $\beta$-thalassemia, were observed. The corresponding figures for marrow reticulocytes were 10.8 and $1.0 \%$, respectively. These findings are compared with results from other forms of $\alpha$-thalassemia in Table I.

\section{Ferrokinetic and red cell survival studies}

The results of the ferrokinetic measurements are shown in Table II. The erythroid iron turnover was approximately five times normal, in keeping with the reversed myeloid/erythroid ratio in the marrow. The reticulocyte production index was increased comparably to almost six times normal (11.6\% reticulocytes with a hematocrit of $36 \%$ ). This suggests that erythropoiesis is largely effective in delivering red cells to the circulation and that the erythroid expansion is a response to an increased rate of peripheral red cell destruction.

The ${ }^{51} \mathrm{Cr}$ red cell studies confirmed a shortened red cell survival, $t_{1 / 2}$ of ${ }^{51} \mathrm{Cr}=14 \mathrm{~d}$. An arithmetic plot (Fig. 2) suggests that there may be two components to the survival curve, with $15 \%$ of the labeled cells having a mean lifespan of $5 \mathrm{~d}$ and the rest a life span of $47 \mathrm{~d}$. This possibility is supported by two other findings. The red cell ${ }^{59} \mathrm{Fe}$ utilization was lower than normal (Fig. 3), which, in the absence of significant intramedullary red cell destruction, is consistent with the early removal of young cells from the circulation. Furthermore, surface counting demonstrated an unexpected accumulation of ${ }^{59} \mathrm{Fe}$ counts over the spleen, reaching a plateau by $4 \mathrm{~d}$ and over the liver, which showed a more gradual rise over the whole $10-d$ period (Fig.
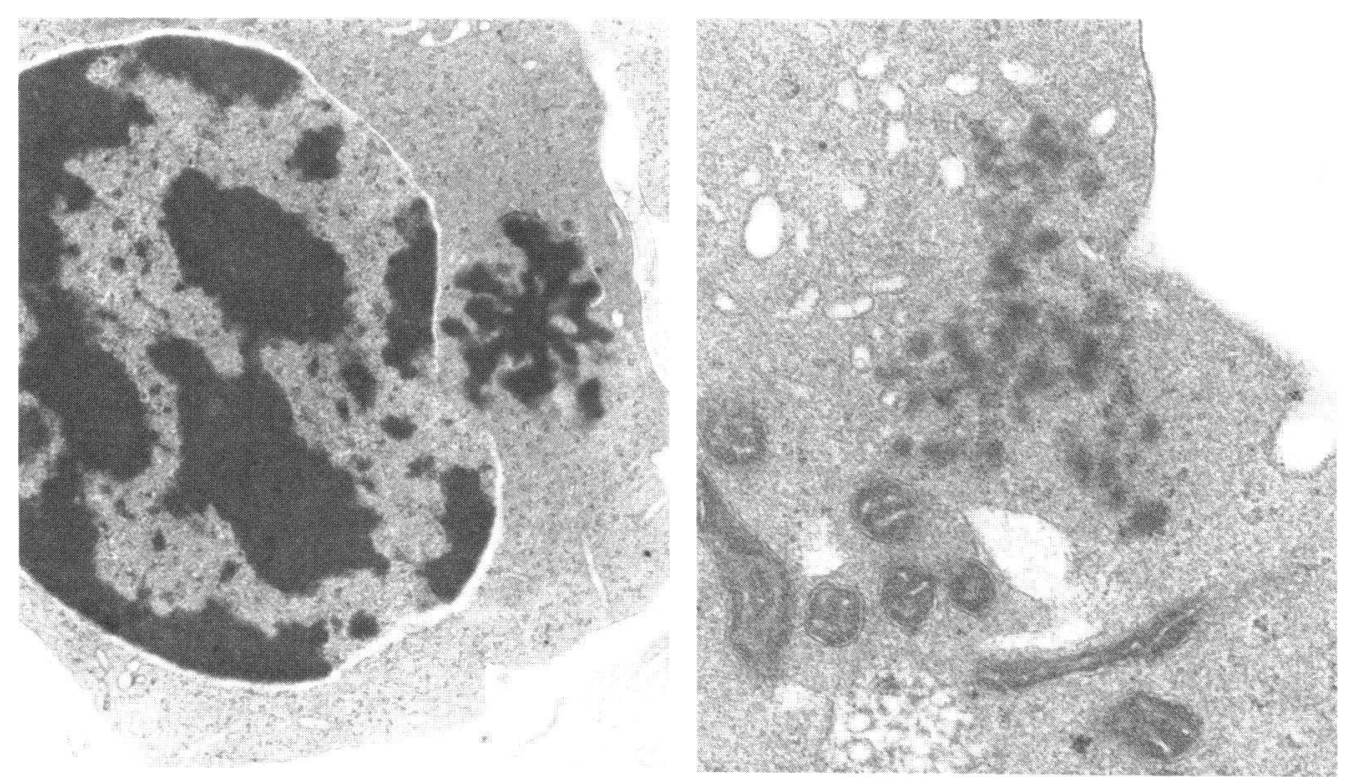

Figure 1. Electron micrographs of bone marrow cells from the HbCS homozygote showing an erythroblast with an intracytoplasmic branching inclusion $(l e f t, \times 17,050)$ and a reticulocyte containing multiple rounded inclusions (right, $\times 45,425)$. 
Table I. Prevalence of Globin Chain Precipitates within the Erythropoietic Cells in Homozygous HbCS Compared with Other Forms of $\alpha$-Thalassemia

\begin{tabular}{|c|c|c|c|c|}
\hline \multirow[b]{2}{*}{$\begin{array}{l}\text { Condition } \\
\text { (No. of cases studied) }\end{array}$} & \multicolumn{2}{|l|}{ \% Erythroblasts with } & \multicolumn{2}{|c|}{$\%$ Nonnucleated ${ }^{*}$ cells with } \\
\hline & Branching inclusions & $\begin{array}{l}\text { Multiple } \\
\text { rounded inclusions }\end{array}$ & Branching inclusions & $\begin{array}{l}\text { Multiple } \\
\text { rounded inclusions }\end{array}$ \\
\hline HbCS homozygote (P.P.) $\ddagger$ & 3.9 & 0.6 & 10.8 & 1.1 \\
\hline$\alpha^{+}$-thal heterozygote $(1) \S$ & 0 & 0.14 & 0.16 & 0 \\
\hline$\alpha^{0}$-thal heterozygote $(2) \S$ & $0.6,1.4$ & $0,0.11$ & $0.8,1.0$ & $0,0.12$ \\
\hline HbH disease $(4) \S$ & $1.1-5.1$ & $0-0.22$ & $2.9-12.0$ & 0 \\
\hline
\end{tabular}

* Containing ribosomes and mitochondria but not including part of a nucleus (i.e., profiles of marrow reticulocytes and some late erythroblasts). $¥ 332$ consecutive erythroblast profiles and 268 consecutive nonnucleated profiles were assessed. $\S$ Data from reference 34 . Inclusion bodies are not observed in erythroblasts of normal individuals.

Thal, thalassemia.

4). In contrast, there were no excess ${ }^{51} \mathrm{Cr}$ counts over these organs during the whole $10-\mathrm{d}$ period. Since ${ }^{59} \mathrm{Fe}$ specifically labels young red cells, while ${ }^{51} \mathrm{Cr}$ labels cells regardless of age, the surface-counting data support the idea of the removal of many young cells soon after release from the marrow. Those cells that survive this early cull seem to have a much longer lifespan of $\sim 50 \mathrm{~d}$.

\section{Hemoglobin analysis}

Quantitation of the various hemoglobin components gave: $\mathrm{HbCS}, 6.8 \%$; $\mathrm{HbA}_{2}, 1.4 \%$; $\mathrm{HbF}, 1.3 \%$; and $\mathrm{Hb}$ Barts, $1.5 \%$, the remainder being $\mathrm{HbA}$.

In order to examine the in vivo stability of $\mathrm{HbCS}, 14 \mathrm{ml}$ of packed red cells from which the buffy coat had been removed were stratified according to age by centrifugation. Starch gel electrophoresis and quantitation of $\mathrm{HbCS}$ after cellulose acetate electrophoresis showed no difference in the proportion of $\mathrm{HbCS}$ between the youngest cells (62\% reticulocytes) and the oldest

Table II. Ferrokinetic Studies on the HbCS Homozygote

\begin{tabular}{lcc}
\hline & P.P. & Normal \\
\hline Plasma iron $(\mu g / d l)$ & 98 & $60-175$ \\
Plasma total iron binding capacity & & \\
$\quad(\mu g / d l)$ & 179 & $250-400$ \\
$\quad$ Hematocrit $(\%)$ & 36 & $47 \pm 7$ \\
Plasma radioiron clearance, $\mathrm{t}_{1 / 2}(\mathrm{~min})$ & 23 & $64-101$ \\
$\quad$ Plasma iron turnover & & \\
$\quad(\mathrm{mg} / \mathrm{dl}$ whole blood per $d)$ & 2.88 & $0.58-0.88$ \\
Erythroid iron turnover & & \\
$\quad(\mathrm{mg} / \mathrm{dl}$ whole blood per $d)$ & 2.66 & $0.50-0.66$ \\
Plasma volume* $(\mathrm{ml} / \mathrm{kg})$ & 45 & $45 \pm 5$ \\
Red cell volume $(\mathrm{ml} / \mathrm{kg})$ & 23 & $30 \pm 5$
\end{tabular}

* Determined from the extrapolated zero time ${ }^{59} \mathrm{Fe}$ counts per milliliter plasma. cells from the bottom of the column ( $0.4 \%$ reticulocytes), as shown in Fig. 5.

Upon storage, HbCS tends to be degraded into the components with fewer amino acids in the $\alpha^{\mathrm{CS}}$-chain ( $\alpha^{\mathrm{CS} 2}-169$ and $\alpha^{\text {CS3 }}-154$ residues), finally ending up as a component designated $\alpha^{\mathrm{CS} 5}$, which has not been characterized structurally but which migrates between $\mathrm{HbF}$ and $\mathrm{HbA}(2,26)$. No difference in the pattern of these components was observed between the old and young red cells on the day they were taken. During storage at $4^{\circ} \mathrm{C}$, these lysates began to accumulate significant amounts of HbCS 2 and HbCS3 after $5 \mathrm{~d}$ and by 2 wk had been almost entirely converted to HbCS5. This degradation pattern did not change consistently between young or old cell lysates but, as reported previously (26), could be almost entirely prevented by

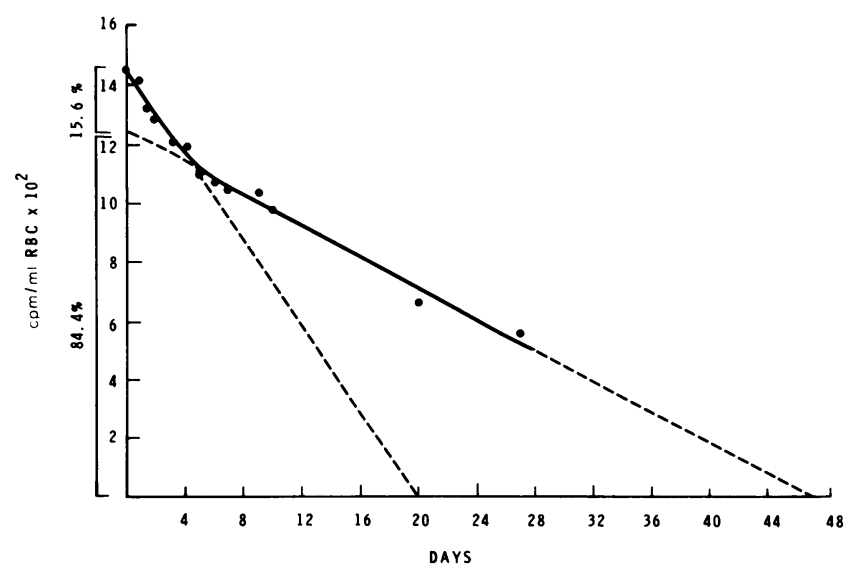

Figure 2. Arithmetic plot of ${ }^{51} \mathrm{Cr}$ autologous red cell survival, analyzed as a double population of cells (19) in the HbCS homozygote. The overall mean cell lifespan $(20 \mathrm{~d})$ arises from the combination of a population of longer lived cells $(84.4 \%$ of total) having a mean cell lifespan of $47 \mathrm{~d}$ and a population (15.6\%) with a mean cell lifespan of $5 \mathrm{~d}$. RBC, erythrocytes. 


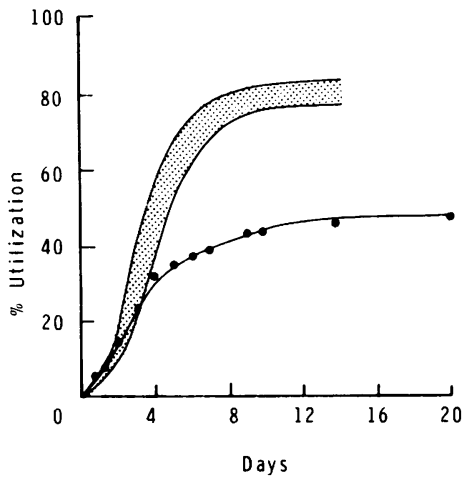

Figure 3. Utilization of ${ }^{59} \mathrm{Fe}$-labeled plasma in the HbCS homozygote compared with normal individuals (shaded curve).

the addition of phenylmethyl sulfonylfluoride (PMSF). The slower changes observed in this study, compared with the previous one (26), may stem from a more rigorous removal of white cells before lysis, as these would be a potent source of proteolytic enzymes.

\section{Globin chain synthesis}

Peripheral blood. The pattern of globin chain synthesis in the peripheral blood reticulocytes of P.P. is shown in Fig. 6 and the results are summarized in Table III. At early time points ( 5 and $10 \mathrm{~min}$ ) a deficit in $\alpha$-chain synthesis was clearly shown, yet with increasing time of incubation the $\alpha / \beta$ synthesis ratio approached unity. Synthesis of the $\alpha^{\mathrm{CS}}$-chain was detectable but at a level of only $2 \%$ of the total $\alpha$-chain synthesis. In three separate incubations it was noticeable that the rate of globin chain synthesis remained linear for only $\mathbf{3 0} \mathrm{min}$, an unusually short time for samples that contain such a high reticulocyte count (21).

The increase in $\alpha / \beta$ ratio with increasing incubation time could be due to a preferential decline in $\beta$-chain synthesis with
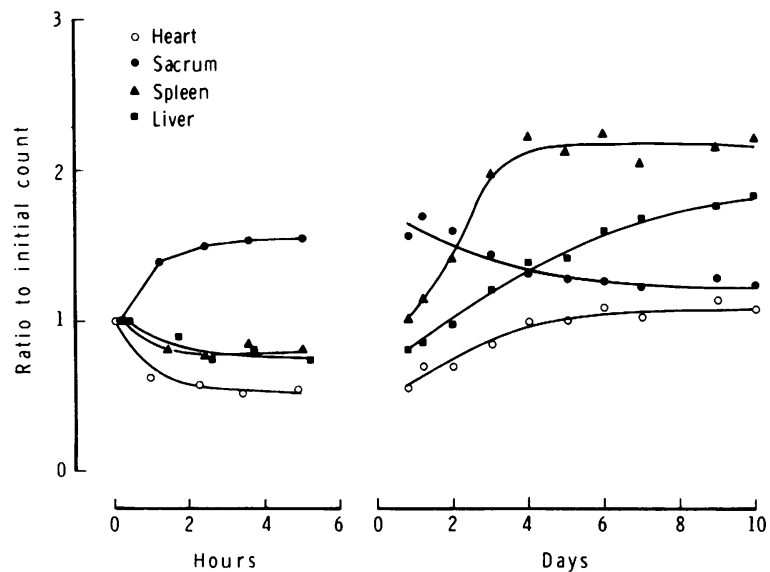

Figure 4. Surface counting of ${ }^{59} \mathrm{Fe}$ over various organs in the HbCS homozygote.

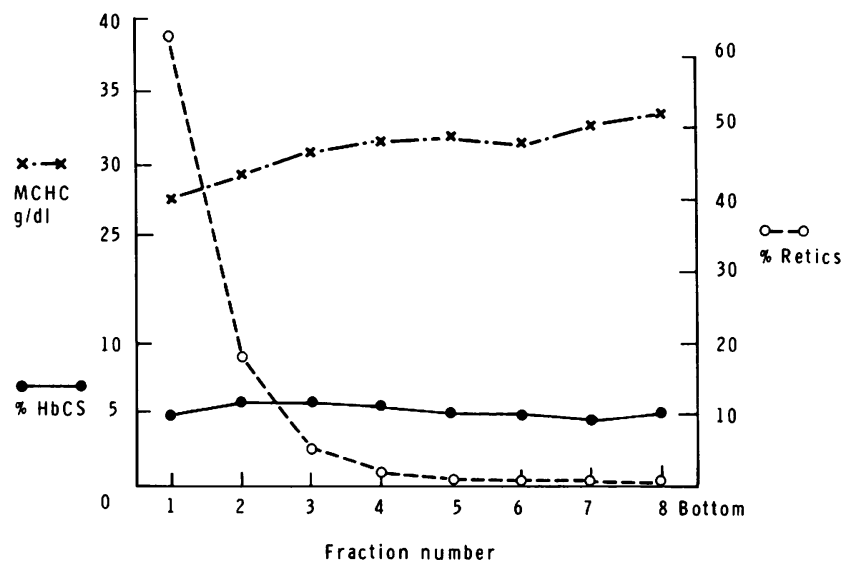

Figure 5. The distribution of HbCS, reticulocytes, and mean corpuscular $\mathrm{Hb}$ concentration in red cells from the HbCS homozygote, age stratified by centrifugation. Retics, reticulocytes.

time, or to degradation of $\beta$-chains (including those newly synthesized) during the incubation period. Evidence supporting the latter explanation was obtained from a pulse-chase experiment in which a $15-\mathrm{min}$ pulse of $\left[{ }^{3} \mathrm{H}\right]$ leucine was followed by a 2-h chase in nonradioactive leucine. Whereas the specific activities of the $\alpha^{\mathrm{A}}$ - and $\alpha^{\mathrm{CS}}$-chains remained unchanged during the chase, the $\beta$-chain specific activity decreased by $35 \%$, resulting in an increase in the $\alpha / \beta$ ratio from 0.77 to 1.10 . This $\beta$-chain degradation is probably due to proteolytic digestion, because when the protease inhibitor PMSF was included in the incubation medium, a much lower increase in the $\alpha / \beta$ ratio was observed over a 60 -min incubation (Table III).

Further evidence for excess $\beta$-chain synthesis at short incubation times was obtained by gel filtration. When stromafree lysate from a 10-min peripheral blood incubation was chromatographed through Sephadex G-75, two radioactive peaks eluted behind the $\mathrm{Hb}$ peak (Fig. 7). When carrier $\mathrm{Hb}$ was added to each of those peaks and the chains were separated, virtually all of the radioactivity eluted with the $\beta$-globin chains in each case; presumably these peaks corresponded to $\beta$-chain dimers and $\beta$-chain monomers. The $\mathrm{Hb}$ peak from this column had an $\alpha / \beta$ chain synthesis ratio of 2.32 , further evidence that there must be a pool of free $\beta$-chains within these cells. When the overall $\alpha / \beta$ ratio was calculated from these three peaks, a value of 0.77 was obtained, compared with a ratio of 0.69 when the same sample was subjected to chain separation directly; this indicates that no substantial chain loss had occurred during removal of the membranes and gel filtration.

Bone marrow. A deficit of $\alpha$-chain synthesis was also demonstrated after incubation of a bone marrow sample (Fig. 6). In this case, however, synthesis of the $\alpha^{\mathrm{CS}}$-chain accounted for $12 \%$ of the total $\alpha$-chain synthesis at $25 \mathrm{~min}$ and its specific activity exceeded that of the $\alpha^{A}$-chain (Table III).

The sample incubated for $60 \mathrm{~min}$ was also centrifuged 


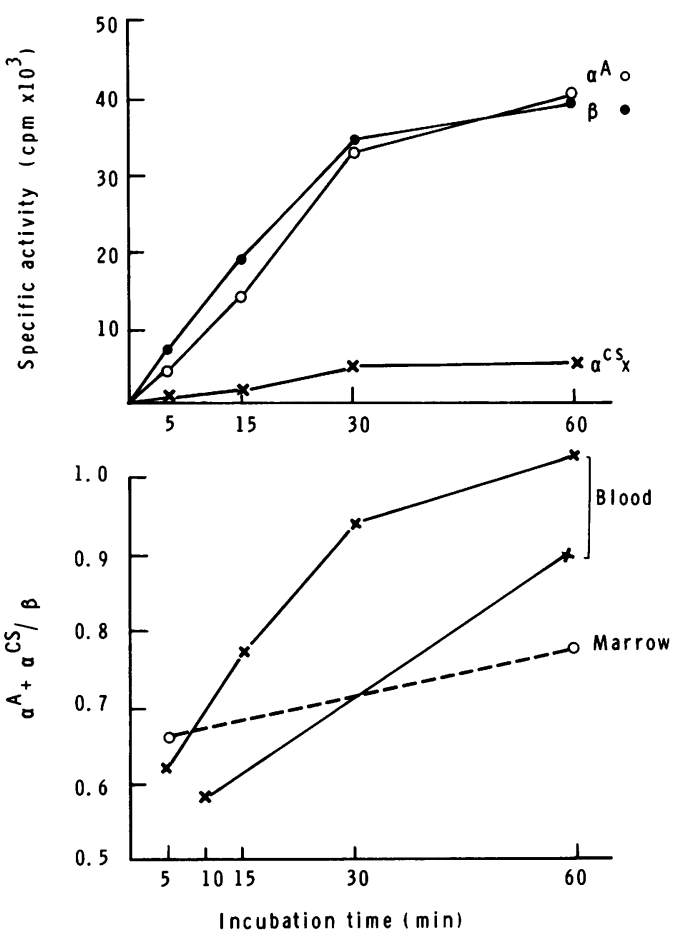

Figure 6. (Top) Specific activities (counts per minute per milligram) of separated globin chains isolated after incubation of peripheral blood from the HbCS homozygote with $\left[{ }^{3} \mathrm{H}\right]$ leucine for increasing periods of time. (Bottom) The change in globin chain specific activity ratios with time in two separate peripheral blood incubations and one bone marrow sample.

through a bovine serum albumin density gradient to fractionate the erythroblasts according to age. The separated cells showed more or less balanced globin synthesis (data not shown), presumably indicating continued proteolysis during the fractionation procedure, since an aliquot converted into globin immediately after incubation had an $\alpha / \beta$ ratio of 0.77 . There was no obvious decline in the proportion of $\alpha^{\mathrm{CS}}$-chain synthesis from the most immature cell fractions that contained mostly basophilic erythroid cells to the mature, orthochromatic normoblast fraction. However, since the $\alpha^{\mathrm{CS}} / \alpha^{\mathrm{A}}$-specific activity ratio was $<1.0(0.7-0.9)$ in the fractions containing immature cells, some degradation of the newly synthesized $\alpha^{\mathrm{CS}}$-chains may have occurred during the fractionation.

\section{Comparison with other forms of $\alpha$-thalassemia}

Time course experiments. Globin chain synthesis was also measured in two patients with $\mathrm{HbH}$ disease $\left(-\alpha^{3.7} /--\right)$, two patients homozygous for $\alpha^{+}$-thalassemia $\left(-\alpha^{3.7} /-\alpha^{3.7}\right)$, and one patient heterozygous for $\alpha^{\circ}$-thalassemia ( $\left.\alpha \alpha /--\right)$; these diagnoses were proven by restriction enzyme mapping (27).

The globin synthesis ratios in these cases after various incubation periods are shown in Fig. 8 and compared with those obtained for the HbCS homozygote. In all cases there was an increase in the $\alpha / \beta$ ratio with increasing incubation time, but it was not as marked as in the HbCS homozygote, not even in the two $\mathrm{HbH}$ disease cases where the $\beta$-chain excess was greatest. When pulse-chase experiments were performed in these samples, there was evidence of $\beta$-chain degradation in each case (Table IV). However, despite the lower $\alpha / \beta$ ratio and hence the greater proportion of excess $\beta$-chains in these cases, the amount of $\beta$ chain degradation was less than in P.P.

Gel filtration. Lysates from incubated reticulocytes were also subjected to gel filtration to estimate the size of the free $\beta$-chain pool in several of these cases (Fig. 9). In both the $\alpha \alpha /--$ and $-\alpha /-\alpha$ patients, no clear peak of $\beta$-chains could be detected (four separate experiments, three patients) at any time between 5 and $60 \mathrm{~min}$ of incubation. In contrast, in the $\mathrm{HbH}$ disease patient $(-\alpha /--)$ the majority of the incorporated radioactivity migrated in a peak after the hemoglobin peak and was shown to be free $\beta$-chains. The relative proportions of counts under the hemoglobin and free $\beta$-chain peaks did not alter appreciably between 5-, 30-, and 60-min incubations.

It seems clear, therefore, that in $\mathrm{HbH}$ disease the newly synthesized $\beta$-chains enter a large $\beta$-chain pool and are not incorporated appreciably into $\mathrm{HbA}$, even after a $1-\mathrm{h}$ incubation; thus the $\mathrm{Hb}$ fraction eluted from the gel filtration column has an $\alpha / \beta$ radioactivity ratio $>4$ (a more precise estimate could not be obtained because of the incomplete separation of the two peaks). In the conditions where two of the four $\alpha$-genes are functional, no free $\beta$-peak can be detected at any time, and the $\alpha / \beta$ radioactivity ratio in the hemoglobin fraction shows the same deficit of $\alpha$-chains as does the unprocessed total globin. In these cases, the excess $\beta$-chains seem to be in the form of tetramers, which contrasts completely with the results obtained in the HbCS homozygote, where, with an overall deficit in $\alpha$ chain production similar to the $-\alpha /-\alpha$ and $\alpha \alpha /--$ conditions, the pattern on gel filtration more closely resembled that of the $\mathrm{HbH}$ disease, with most of the $\beta$-chains in a nontetramer form.

Bone marrow incubation in $-\alpha /-\alpha$. Bone marrow cells from one patient with the $-\alpha /-\alpha$ genotype gave $\alpha / \beta$ ratios of 0.66 and 0.93 after 5 and $60 \mathrm{~min}$ of incubation, respectively. This is higher than the ratio obtained in peripheral blood cells of the same patient ( $\alpha / \beta=0.42-0.53$ over a $15-60$-min time course), possibly reflecting greater proteolytic activity in nucleated cells.

When the 5-min marrow incubation was subjected to gel filtration, no pool of free $\beta$-chains was observed and the $\alpha / \beta$ ratio of the $\mathrm{Hb}$ fraction was 0.65 , identical with the ratio obtained from the whole globin sample. Similarly, after the addition of nonradioactive $\mathrm{HbH}$, another aliquot chromatographed on Amberlite IRC 50 produced no radioactive globin chains in the $\mathrm{HbH}$ peak eluted at $4^{\circ} \mathrm{C}$ and an $\alpha / \beta$ ratio of 0.66 in the $\mathrm{HbA}$ peak eluted at room temperature.

It is not clear how an excess of newly synthesized $\beta$-chains can occur in these cells yet not be detected either as $\beta$-chain dimers/monomers or as $\beta_{4}$-tetramers $(\mathrm{HbH})$, unless there is 
Table III. Globin Chain Synthesis Results in Three Separate Blood Samples from the HbCS Homozygote

\begin{tabular}{|c|c|c|c|c|c|c|c|c|}
\hline \multirow[b]{2}{*}{ Experiment } & \multirow[b]{2}{*}{ Incubation period } & \multicolumn{2}{|l|}{ Total counts } & \multicolumn{5}{|c|}{ Specific activities } \\
\hline & & $\left(\alpha^{\wedge}+\alpha^{\complement S}\right) / \beta$ & $\% \alpha^{\alpha s}$ & $\alpha^{\wedge}$ & $\alpha^{c s}$ & $\beta$ & $\alpha^{\wedge} / \beta$ & $\alpha^{\mathrm{CS}} / \alpha^{\wedge}$ \\
\hline & $\min$ & & & $c p m / m g$ & $c p m / m g$ & $\mathrm{cpm} / \mathrm{mg}$ & $\mathrm{cpm} / \mathrm{mg}$ & $\mathrm{cpm} / \mathrm{mg}$ \\
\hline \multirow[t]{2}{*}{ PB I } & 10 & 0.58 & 2.5 & 7,128 & 1,072 & 11,401 & 0.63 & 0.15 \\
\hline & 60 & 0.91 & 1.3 & 20,400 & 2,906 & 21,043 & 0.97 & 0.14 \\
\hline \multirow[t]{5}{*}{ PB II } & 5 & 0.62 & 3.0 & 4,478 & 966 & 6,646 & 0.68 & 0.21 \\
\hline & 15 & 0.77 & 2.0 & 14,011 & 1,854 & 18,771 & 0.75 & 0.13 \\
\hline & $15+2-h$ chase & 1.10 & 1.7 & 14,227 & 1,821 & 12,180 & 1.17 & 0.13 \\
\hline & 30 & 0.94 & 1.6 & 32,740 & 5,941 & 34,465 & 0.95 & 0.18 \\
\hline & 60 & 1.03 & 2.0 & 40,328 & 6,572 & 39,705 & 1.01 & 0.16 \\
\hline \multirow[t]{2}{*}{ PB III } & 10 & 0.69 & 1.5 & 11,360 & 2,512 & 14,968 & 0.76 & 0.22 \\
\hline & $60+$ PMSF & 0.78 & 2.0 & 32,691 & 9,775 & 37,958 & 0.86 & 0.30 \\
\hline \multirow[t]{2}{*}{ BM I } & 5 & 0.64 & 12.3 & 23,000 & 31,651 & 38,914 & 0.59 & 1.38 \\
\hline & 60 & 0.77 & 8.1 & 159,600 & 170,512 & 217,008 & 0.76 & 1.06 \\
\hline
\end{tabular}

PB, peripheral blood; BM, bone marrow.

considerable exchange of subunits with preformed $\mathrm{HbA}$ tetramers.

\section{Discussion}

The various phenotypes associated with different molecular variations of $\alpha$-thalassemia have been reviewed recently (28).
$\alpha^{+}$-Thalassemia carriers, who have a single $\alpha$-gene deletion $(-\alpha / \alpha \alpha)$ have, at most, a very mild reduction in their $\mathrm{MCH}$ and MCV values; $\alpha^{\circ}$-thalassemia heterozygotes $(--/ \alpha \alpha)$ and $\alpha^{+}$thalassemia homozygotes $(-\alpha /-\alpha)$, who each have two deleted $\alpha$-globin genes, have mild anemia with reduced $\mathrm{MCH}$ and MCV values and are phenotypically indistinguishable. The effect of the $\alpha^{\mathrm{CS}}$-gene is to reduce the output of $\alpha$-globin chains from

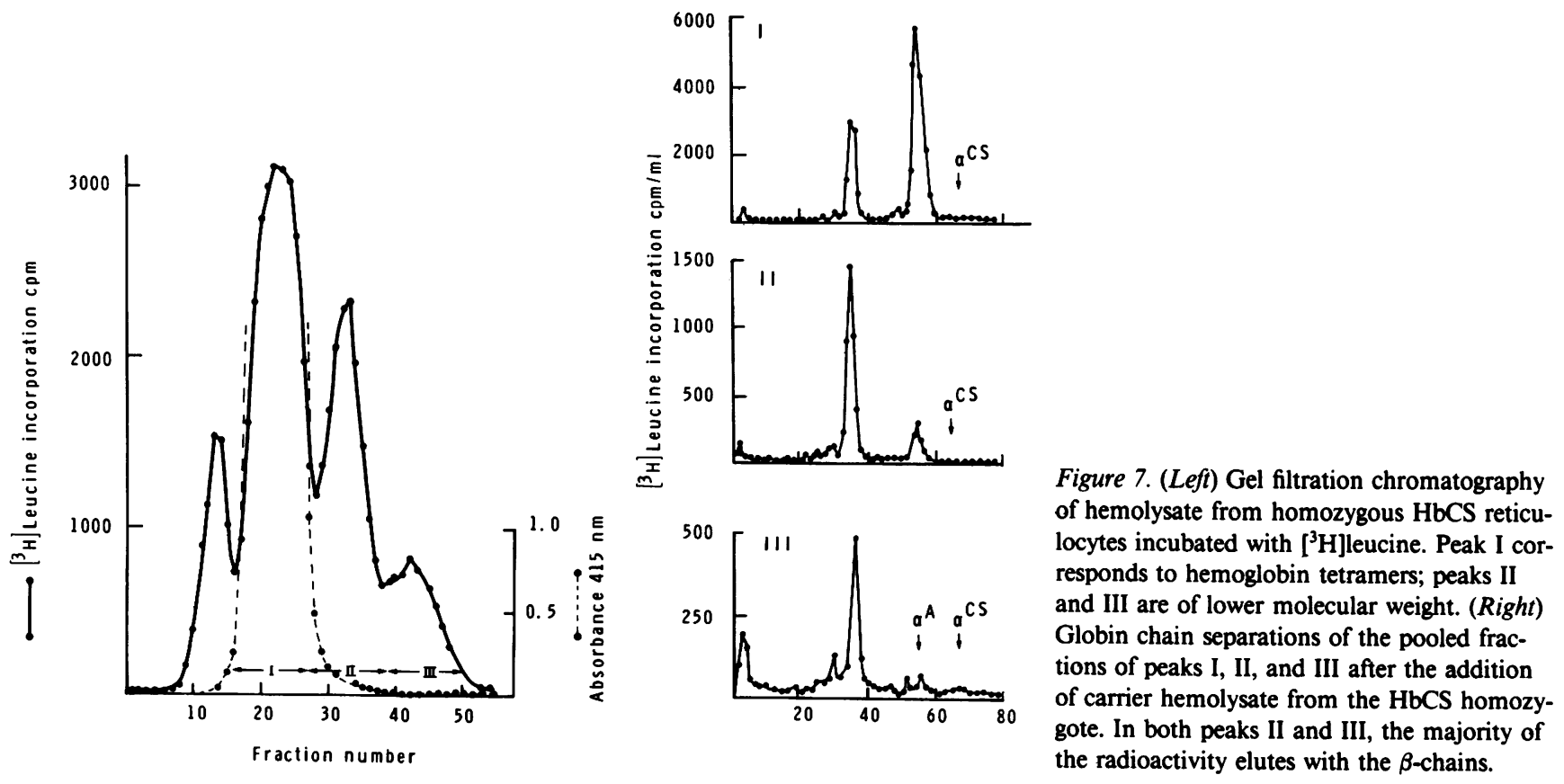




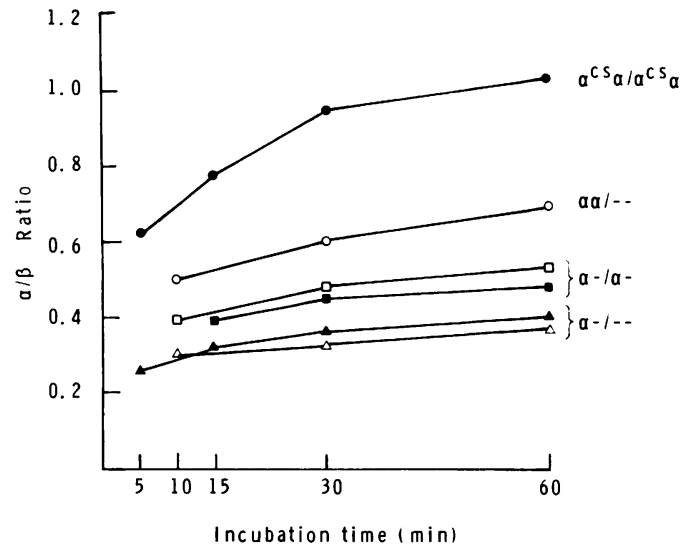

Figure 8. Globin chain synthesis ratios after various incubation periods in the HbCS homozygote compared with various types of deletion $\alpha$-thalassemia.

the $\alpha 2$-locus to $\sim 1-2 \%$ of normal. For this reason, HbCS heterozygotes should be phenotypically similar to $\alpha^{+}$-thalassemia heterozygotes, and this is the case; i.e., they have mild hematological changes and a slightly elevated level of $\mathrm{Hb}$ Barts at birth (7). However, HbCS homozygotes are not phenotypically the same as $\alpha^{+}$-thalassemia homozygotes. The findings in the $\mathrm{HbCS}$ homozygote described here are identical to those previously described $(6,8,9)$. The patient had a moderate degree of anemia with an elevated reticulocyte count, marked basophilic stippling of the red cells, an almost normal $\mathrm{MCH}$ value, a normal $\mathrm{MCV}$ value, and an elevated level of $\mathrm{Hb}$ Barts. These findings, together with the increasing evidence that $--/ \alpha^{\mathrm{Cs}} \alpha$ individuals have a more severe form of $\mathrm{HbH}$ disease than those with the $--/-\alpha$ arrangement $(10,11)$ indicate that the pathophysiology of the HbCS mutation is different from that of the deletion forms of $\alpha$-thalassemia.

Previous work on the synthesis of HbCS has shown that, unlike other forms of $\alpha$-thalassemia, both heterozygotes and homozygotes seem to have excess $\alpha$-chains $(5,6)$, despite a deficit of $\alpha$-mRNA (3). The present studies have resolved this anomaly, clearly demonstrating a deficit of $\alpha$-chain production when erythroid cells were incubated for short periods. With increasing periods of incubation, the excess $\beta$-chain radioactivity was gradually lost and the $\alpha / \beta$ globin chain synthesis ratios approached those reported in the literature. Furthermore, the rate of globin chain synthesis remained linear in the cells of the HbCS homozygote for only $30 \mathrm{~min}$, an unexpectedly short time for samples with such a high reticulocyte count. This fact, together with the rapid removal of the excess $\beta$-chains, presumably accounts for the high $\alpha / \beta$ ratios observed by other workers in their 2-3-h incubations of the cells of HbCS homozygotes.

Thus, the clinical and hematological findings in the HbCS homozygotes seem to arise from the following series of events.
After transcription of the $\alpha^{\mathrm{CS}}$-gene (whether this is at a normal or subnormal level is not yet known) there is instability of the $\alpha^{\mathrm{CS}}$-mRNA, which decreases during erythroid maturation and which is virtually absent from reticulocytes $(3,30)$. The synthesis of $\alpha^{\mathrm{Cs}}$-chains follows the same pattern, decreasing from bone marrow to reticulocytes $(2,31)$; but once incorporated into a hemoglobin tetramer, the $\alpha^{\mathrm{cs}}$-chains seem to be quite stable in vivo. As a result of the deficit of $\alpha^{\mathrm{CS}}$-chain synthesis, excess $\beta$ chains accumulate in the red cells and are detectable as a pool of $\beta$-chain dimers and monomers. However, this pool seems to turn over rapidly, probably as a result of proteolysis, and is destroyed at a rate greater than that seen in other forms of $\alpha$ thalassemia with a comparable or even greater deficit of $\alpha$-chain synthesis. The net result of these events is that many of the erythrocytes emerging from the bone marrow are recognized as abnormal by the spleen and are rapidly removed from the circulation, resulting in hemolysis and splenomegaly. It seems that those cells that survive this early cull have a more normal lifespan.

This course of events does not explain why the phenotype of homozygous HbCS differs to such a degree from deletion forms of $\alpha$-thalassemia with comparable deficits in $\alpha$-chain production. In many ways the findings in our patient homozygous for $\mathrm{HbCS}$ are similar to those in $\mathrm{HbH}$ disease, albeit the overall degree of chain imbalance is less in HbCS. The presence of a short-lived red cell population has been described in $\mathrm{HbH}$ disease (29), while the electron-microscopic appearances of the HbCS red cell precursors are closer to those of $\mathrm{HbH}$ disease than to the different $\alpha$-thalassemia carrier states. Similarly, the gel filtration experiments show that, as in $\mathrm{HbH}$ disease, HbCS ho-

Table IV. Globin Chain Specific Activities in Pulse-Chase Experiments Using Peripheral Blood from the $\mathrm{HbCS}$ Homozygote and from Two Individuals with Deletion Forms of $\alpha$-Thalassemia

\begin{tabular}{|c|c|c|c|c|c|c|}
\hline \multirow[b]{2}{*}{ Case } & \multirow[b]{2}{*}{ Pulse } & \multirow[b]{2}{*}{ Chase } & \multicolumn{2}{|l|}{ SA } & \multirow{2}{*}{$\begin{array}{l}\mathrm{SA}_{a} / \\
\mathrm{SA}_{\boldsymbol{\theta}}\end{array}$} & \multirow{2}{*}{$\begin{array}{l}\% \text { Decrease } \\
\text { in } \mathrm{SA}_{\beta}\end{array}$} \\
\hline & & & $\alpha^{\wedge}$ & $\beta$ & & \\
\hline & $\min$ & $\min$ & $\mathrm{cpm} / \mathrm{mg}$ & $c p m / m g$ & & \\
\hline \multirow[t]{2}{*}{$\alpha^{\mathrm{CS}} \alpha / \alpha^{\mathrm{CS}} \alpha$} & 15 & - & 14,011 & 18,771 & 0.75 & \multirow{2}{*}{35.1} \\
\hline & 15 & 120 & 14,227 & 12,180 & 1.17 & \\
\hline \multirow[t]{2}{*}{$\alpha-/ \alpha-$} & 10 & - & 231 & 669 & 0.35 & \multirow{2}{*}{20.4} \\
\hline & 10 & 120 & 250 & 532 & 0.47 & \\
\hline \multirow[t]{2}{*}{$\alpha-/ \alpha-$} & 30 & - & 792 & 1,666 & 0.48 & \multirow{2}{*}{25.0} \\
\hline & 30 & 120 & 751 & 1,250 & 0.60 & \\
\hline \multirow[t]{2}{*}{$\alpha-/--$} & 15 & - & 10,678 & 28,149 & 0.38 & \multirow{2}{*}{23.1} \\
\hline & 15 & 120 & 10,456 & 21,651 & 0.48 & \\
\hline
\end{tabular}

SA, specific activity. 


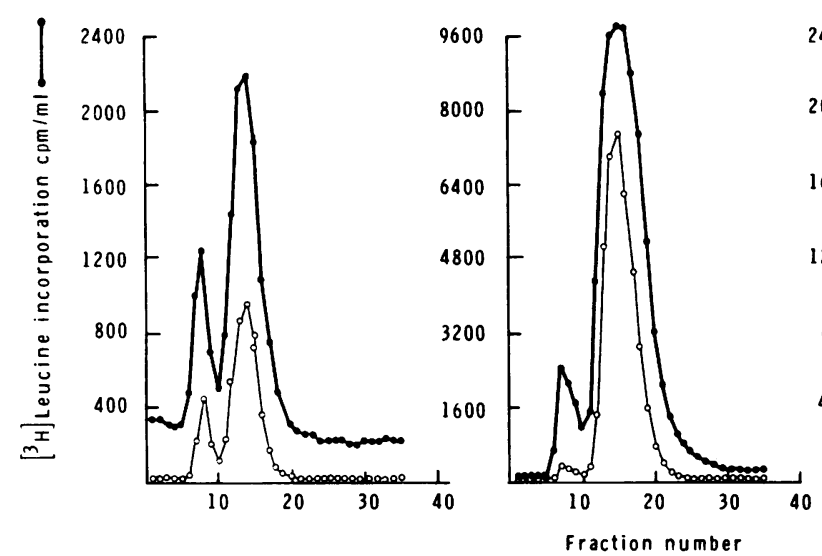

mozygotes have a large pool of free $\beta$-chains in their red cells that could not be demonstrated in the cells of $\alpha^{\circ}$-thalassemia heterozygotes or $\alpha^{+}$-thalassemia homozygotes. Is it possible. therefore, that there is a greater deficit in $\alpha$-chain synthesis in HbCS than is revealed even by short time point incubations? The $\alpha^{\mathrm{CS}}$-mutation occurs in the $\alpha 2$-globin gene $(28,30,32)$ and, while mRNA quantitation suggests a twofold excess of $\alpha 2$ over $\alpha 1$-mRNA in normal individuals $(28,30,32)$, this difference appears to be compensated for by differential translation, producing equal proportions of $\alpha$-chain from each gene (33). There is no evidence from quantitation of other abnormal $\alpha$-chain variants that the output of $\alpha$-chains directed by each gene differs significantly, and an individual homozygous for an $\alpha 2$-gene deletion $\left(-\alpha^{4.2} /-\alpha^{4.2}\right)$ is hematologically indistinguishable from any other individual with an $\alpha$-gene deletion condition in which only two genes remain active (unpublished observation). It seems unlikely, therefore, that in HbCS the overall degree of $\alpha$-chain production is significantly less than that in the deletion conditions in which only two $\alpha$-genes remain; this suggests that the abnormal pattern of translation of the $\alpha^{\mathrm{CS}}$-mRNA may itself be responsible for the other abnormalities in homozygous HbCS cells, although how this might affect the rate of proteolysis is not at all clear.

Whatever the mechanism, these studies provide clear evidence for a significant overall deficit of $\alpha$-chain production in the red cell precursors of an HbCS homozygote and show that there is both precipitation and rapid destruction of excess $\beta$ chains. These processes probably lead to damage to the red cell membrane, shortened red cell survival, and the marked reticulocytosis and splenomegaly that characterize this particular $\alpha$ thalassemia syndrome.

\section{Acknowledgments}

We wish to thank P.P. for his cooperation in these studies, Dr. C. Barton for referring patients with $\alpha$-thalassemia, and Dr. D. R. Higgs for the gene mapping.

This work was supported in part by the Rockefeller Foundation and a grant (AM 09805) from the National Institute of Arthritis, Diabetes, Digestive and Kidney Diseases.

\section{References}

1. Clegg, J. B., D. J. Weatherall, and P. F. Milner. 1971. Haemoglobin Constant Spring-a chain termination mutant? Nature (Lond.). 234:337340 .

2. Weatherall, D. J., and J. B. Clegg. 1975. The $\alpha$-chain termination mutants and their relation to the $\alpha$-thalassaemias. Philos. Trans. R. Soc. Lond. B. Biol. Sci. 271:411-455.

3. Hunt, D. M., D. R. Higgs, P. Winichagoon, J. B. Clegg, and D. J. Weatherall. 1982. Haemoglobin Constant Spring has an unstable $\alpha$ chain messenger RNA. Br. J. Haematol. 51:405-413.

4. Milner, P. F., J. B. Clegg, and D. J. Weatherall. 1971. Haemoglobin $\mathrm{H}$ disease due to a unique haemoglobin variant with an elongated $\alpha$ chain. Lancet. I:729-732.

5. Pongsamart, S., S. Pootrakul, P. Wasi, and S. Na-Nakorn. 1975. Hemoglobin Constant Spring: hemoglobin synthesis in heterozygous and homozygous states. Biochem. Biophys. Res. Commun. 64:681-686.

6. Pootrakul, P., P. Winichagoon, S. Fucharoen, P. Pravatmuang, A. Piankijagum, and P. Wasi. 1981. Homozygous haemoglobin Constant Spring: a need for revision of concept. Hum. Genet. 59:250-255.

7. Weatherall, D. J., and J. B. Clegg. 1981. The Thalassaemia Syndromes. Blackwell Scientific Publications, Oxford. Third ed. 508-612.

8. Lie-Injo, L. E., J. Ganesan, J. B. Clegg, and D. J. Weatherall. 1974. Homozygous state for $\mathrm{Hb}$ Constant Spring (slow-moving Hb X components). Blood. 43:251-259.

9. Lie-Injo, L. E., J. Ganesan, and C. G. Lopez. 1975. The clinical, haematological and biochemical expression of hemoglobin Constant Spring and its distribution. In Abnormal Hemoglobins and Thalassemia. R. M. Schmidt, editor. Academic Press, New York. 275-291.

10. Winichagoon, P., P. Adirojnanon, and P. Wasi. 1980. Levels of haemoglobin $\mathrm{H}$ and proportions of red cells with inclusion bodies in the two types of haemoglobin $\mathrm{H}$ disease. Br. J. Haematol. 46:507-509.

11. Wasi, P., S. Pootrakul, P. Pootrakul, P. Pravatmuang, P. Winichagoon, and S. Fucharoen. 1981. Thalassemia in Thailand. Ann. N.Y. Acad. Sci. 344:352-363.

12. Higgs, D. R., D. M. Hunt, H. C. Drysdale, J. B. Clegg, L. Pressley, and D. J. Weatherall. 1980. The genetic basis of $\mathrm{Hb}$ Q-H disease. $\mathrm{Br}$. J. Haematol. 46:387-400. 
13. Wood, W. G. 1982. Hemoglobin analysis. In Methods in Hematology. D. J. Weatherall, editor. Churchill Livingstone, Edinburgh. 6:31-53.

14. Wickramasinghe, S. N., M. Hughes, S. R. Hollan, M. Horanyi, and J. Szelenyi. 1980. Electron microscope and high resolution autoradiographic studies of the erythroblasts in haemoglobin $\mathrm{H}$ disease. $\mathrm{Br}$. J. Haematol. 45:401-404.

15. Wood, W. G., and G. Stamatoyannopoulos. 1975. Globin synthesis in fractionated normoblasts of $\beta$-thalassaemia heterozygotes. $J$. Clin. Invest. 55:567-578.

16. Cook, J. D., and C. A. Finch. 1980. Ferrokinetic measurements. In Methods in Hematology. J. D. Cook, editor. Churchill Livingstone, Edinburgh. 1:134-147.

17. International Committee for Standardization in Haematology. 1978. Recommendations for measurement of serum iron in human blood. Br. J. Haematol. 38:291-294.

18. International Committee for Standardization in Haematology. 1978. The measurement of total and unsaturated iron-binding capacity in serum. Br. J. Haematol. 38:281-291.

19. International Committee for Standardization in Haematology. 1980. Recommended method for radioisotope red-cell survival studies. Br. J. Haematol. 45:659-666.

20. Dacie, J. W., and S. M. Lewis. 1975. Practical Haematology. Churchill Livingstone, Edinburgh. Fifth ed.

21. Clegg, J. B. 1982. Hemoglobin synthesis. In Methods in Hematology. D. J. Weatherall, editor. Churchill Livingstone, Edinburgh. 6:54-73.

22. Beutler, E., C. West, and K. G. Beume. 1976. The removal of leucocytes and platelets from whole blood. J. Lab. Clin. Med. 88:328333.

23. Allen, D. W., W. A. Schroeder, and J. Balog. 1958. Observations on the chromatographic heterogeneity of normal adult and foetal haemoglobins. J. Am. Chem. Soc. 80:1628-1634.

24. Clegg, J. B., and D. J. Weatherall. 1967. Haemoglobin synthesis in $\alpha$-thalassemia (haemoglobin $\mathrm{H}$ disease). Nature (Lond.). 215:12411243.

25. Clegg, J. B., M. A. Naughton, and D. J. Weatherall. 1966. Abnormal human haemoglobins. Separation and characterisation of the $\alpha$ and $\beta$ chains by chromatography and the determination of two new variants, $\mathrm{Hb}$ Chesapeake and Hb J (Bangkok). J. Mol. Biol. 19:91-108.

26. Pootrakul, S., B. Kemathorn, P. Pravatmuang, S. Pongsamart, and S. Na-Nakorn. 1976. Hemoglobin Constant Spring: degradation and synthesis studies. Excerpta Med. Int. Congr. Ser. 415:310-314.

27. Old, J. M., and D. R. Higgs. 1982. Gene analysis. In Methods in Hematology. D. J. Weatherall, editor. Churchill Livingstone, Edinburgh. 6:74-102.

28. Higgs, D. R., and D. J. Weatherall. 1983. Alpha-thalassemia. Curr. Top. Haematol. 4:37-97.

29. Barosi, G., A. Baraldi, F. Bonomi, M. Cazzola, M. Dacco, P. Spriano, and M. Stefanelli. 1983. Competing models for the analysis of red cell survival obtained with a ${ }^{51} \mathrm{Cr}$ labelling technique. Scand. $J$. Haematol. 31:381-388.

30. Liebhaber, S. A., and Y. W. Kan. 1981. Differentiation of the mRNA transcripts originating from the $\alpha 1$ - and $\alpha 2$-globin loci in normals and $\alpha$-thalassemics. J. Clin. Invest. 68:439-446.

31. Kan, Y. W., D. Todd, and A. M. Dozy. 1974. Haemoglobin Constant Spring synthesis in red cell precursors. Br. J. Haematol. 28:103106.

32. Orkin, S. H., and S. C. Goff. 1981. The duplicated human $\alpha-$ globin genes: their relative expression as measured by RNA analysis. Cell. 24:345-351.

33. Liebhaber, S. A., and Y. W. Kan. 1982. Different rates of mRNA translation balance the expression of the two human $\alpha$-globin loci. $J$. Biol. Chem. 257:11852-11855.

34. Wickramasinghe, S. N., M. Hughes, S. Fucharoen, and P. Wasi. 1984. The fate of excess $\beta$ globin chains within erythropoietic cells in $\alpha$-thalassaemia $2, \alpha$-thalassaemia 1 , haemoglobin- $H$ disease and haemoglobin Q-H disease: an electron microscope study. Br. J. Haematol. $56: 473-482$. 